\title{
Kahramanmaraş İli Pazarcık İlçesinde Mısır Üretim Faaliyetinin Ekonomik Analizi
}

\section{Mücahit PAKSOY Duran ORTASÖZ D \\ KSÜ Ziraat Fakültesi Tarım Ekonomisi Bölümü, Avşar Kampüsü, Kahramanmaraş \\ $\bowtie$ : mpaksoy@ksu.edu.tr}

\section{ÖZET}

$\mathrm{Bu}$ çalışmanın temel amacı, Kahramanmaraş ili Pazarcık ilçesinde silajlık ve dane mısır üretim faaliyetinin ekonomik analizini ortaya koymaktır. Çalışmanın ana materyalini 2014 üretim yılında mısır üretimi yapan işletmeler arasından basit tesadüfï örnekleme yöntemi ile belirlenen 55 işletmeden anket yoluyla elde edilen veriler oluşturmaktadır. İşletmelerde dane mısır üretimi için; dekara toplam masraf içindeki değişken masrafların payı \%81,80, sabit masrafların payı ise \%18,20 olarak hesaplanmıştır. Değişken masraflar içerisindeki en büyük payı gübreleme ve iş̧̧iliğinin aldığı, bunu diğer değişken masraflardan tohum, sulama ve iş̧̧iliğinin takip ettiği belirlenmiş̧ir. Bölgede ortalama dane mısır ana ürün verimi 1080,43 $\mathrm{kg} / \mathrm{da}$ olarak bulunmuştur. Buna bağlı olarak $1 \mathrm{~kg}$ dane mısır maliyeti $0,49 \mathrm{TL} / \mathrm{kg}$, satış fiyatı $0,544 \mathrm{TL} / \mathrm{kg}$, devlet desteği $0,04 \mathrm{TL} / \mathrm{kg}$ net kar ise $0,094 \mathrm{TL} / \mathrm{kg}$ olarak hesaplanmıştır. İşletmelerde silajlık mısır üretimi için; dekara toplam masraf içindeki değişken masrafların payı $\% 83,44$, sabit masrafların ise \%16,56 olarak hesaplanmıştır. Değişken masraflar içerisindeki en büyük payı ise yine gübreleme ve işçiliğinin aldığı, bunu diğer değişken masraflardan tohum, sulama ve işçiliği ile taşıma masraflarının takip ettiği tespit edilmiştir. Bölgede ortalama silajlı mısır ana ürün verimi $5188,89 \mathrm{~kg} / \mathrm{da}$ olarak bulunmuştur. Buna bağlı olarak $1 \mathrm{~kg}$ silajlık mısır maliyeti $0,11 \mathrm{TL} / \mathrm{kg}$ satış fiyatı $0,122 \mathrm{TL} / \mathrm{kg}$ devlet desteği $0,014 \mathrm{TL} / \mathrm{kg}$ net kar ise $0,0136 \mathrm{TL} / \mathrm{kg}$ olarak hesaplanmıştır. Dane ve silajlık mısır üretim maliyetleri ile ürün satış fiyatları karşılaştırıldığında, çiftçilerin tarımsal destekler olmadan, yüksek girdi fiyatlarını karşılamakta güçlük çektikleri görülmektedir. $\mathrm{Bu}$ sebeple prim desteklerinin ve diğer girdi desteklerinin arttırılması önerilmektedir.

\author{
Makale Tarihçesi \\ Geliş : 21.10.2018 \\ Kabul : 27.12.2018
}

\section{Anahtar Kelimeler \\ Dane Misir, \\ Silajlık Mısır, \\ Kahramanmaraş, \\ Maliyet}

\section{Araştırma Makalesi}

\section{Economic Analysis of Corn Production in Pazarcik District of Kahramanmaraş Province}

\section{ABSTRACT}

The main purpose of this research was to reveal the economic analysis of silage and grain corn production activities in Pazarcik county of Kahramanmaraş province. The main material of this study constitute from data gathered through the survey of 55 producers determined by stratified sampling method in 2014 . The share of variable costs in total costs per hectare for grain corn production in enterprises calculated $81,80 \%$ of fixed costs at a rate of $18,20 \%$. Fertilization and labor have the largest share in variable costs, other variable costs such as seed, irrigation and labor followed this respectively. Average grain yield of the corn in the region was found 1080,43 kg/decare. Accordingly, the cost of $1 \mathrm{~kg}$ of corn grain $0,49 \mathrm{TL} / \mathrm{kg}$, the selling price $0,544 \mathrm{TL} / \mathrm{kg}$, government support $0.04 \mathrm{TL} / \mathrm{kg}$, net profit $0,094 \mathrm{TL} / \mathrm{kg}$ was calculated. The share of variable costs in total costs per hectare for silage corn production in enterprises calculated at a rate of $83,44 \%$ and fixed costs16,56\%. Fertilizing and workmanship were again the largest share in variable costs, other variable costs such as seed, irrigation and labor costs, transportation, were followed this respectively. Average silage corn yield in the region was found $5188,89 / \mathrm{kg}$.
Article History

Received : 21.10.2018

Accepted : 27.12.2018

\section{Keywords}

Grain Corn,

Silage Corn,

Kahramanmaraş,

Economic Analysis

Research Article 
Accordingly, $1 \mathrm{~kg}$ of silage corn cost $0,11 \mathrm{TL} / \mathrm{kg}$ selling price 0,122 $\mathrm{TL} / \mathrm{kg}$ government support $0,014 \mathrm{TL} / \mathrm{kg}$, net profit $0,0136 \mathrm{TL} / \mathrm{kg}$ was calculated. When grain and silage corn production costs compared with sales prices, farmers have difficulty in meeting higher input prices without agricultural support. For this reason, raises in premium and other input supports are recommended.

To cite: Paksoy M, Ortasöz N 2018. Kahramanmaraş İli Pazarcık İlçesinde Mısır Üretim Faaliyetinin Ekonomik Analizi. KSÜ Tar Doğa Derg 21(Özel Sayl) : 95-101, DOI : 10.18016/ ksutarimdoga.vi.472962

\section{GİRIŞ}

Dünyada üretilen mısırın \%27'si insan beslenmesinde, \%73'ü ise hayvan yemi olarak kullanılmaktadır. Bu oranlar gelişmekte olan ülkelerde sirasıyla $\% 54$ ve $\% 46$, gelişmiş ülkelerde ise $\% 10$ ve $\% 90$ 'dır. Dünyada insan beslenmesinde tüketilen günlük kalorinin \%11’i mısır bitkisinden sağlanmaktadır. Bu oran gelişmiş ülkelerde \%4'e düşerken, Meksika ve Orta Amerika gibi ülkelere \%27'ye kadar yükselmektedir. Mısırın endüstride kullanımı diğer tahıllara göre artmış, gün geçtikçe de artmaktadır. Bunun sebebi; birim alandan yüksek verim alınması, yetiştirme tekniği, hasat, nakliyeve depolama gibi işlemlerinin kolay oluşu ve sürekli geliştirilme özelliğine sahip olmasıdır (Anonim, 2016a).

Mısır dünyada tahıllar içinde üretim açısından buğdaydan sonra ikinci sırada yer alır, bunu çeltik takip eder. Gelişmekte olan ülkeler içinde mısır Asya'da buğday ve çeltikten sonra yer alırken, Latin Amerika ve Afrika'da birinci sırada yer alır. Mısır, hayvan yemi ve insan yiyeceği olarak çok değişik alanlarda kullanılan ve Türkiye'de buğday ve arpadan sonra en fazla üretilen hububat bitkisidir. Türkiye'de misırın geleneksel üretim alanları Karadeniz ve Güney Marmara bölgesi olarak bilinir. Türkiye'nin hemen her yerinde yetiştirilen misır, yakın zamana kadar yaygın bir şekilde sadece Karadeniz Bölgesinde yetiştirilmekte iken 1980'li yıllardan itibaren özellikle Tarım Bakanlığı tarafından yürütülen II. ürün projesi ile güney bölgelerimizde de üretim alanları artmıştır (Anonim, 2016a).

Türkiye'de 2014 yılı itibariyle toplam dane mısır ekim alanı 6.590.000 dekar olup, Kahramanmaraş ilinin payı \%4,42'dir. Türkiye'de silajlık mısır ekim alanı ise 10.627.140 da olup, Kahramanmaraş ilinin payı \%0,58'dir. Kahramanmaraş ilinde dane mısır ekiminin \%29'u, silajlık mısır ekiminin ise \%28'i Pazarcık ilçesinde yapılmaktadır. Pazarcık ilçesinde 2014 yılında toplam dane mısır ekim alanı 79.421 da silajlık mısır ekim alanı ise 13.000 da'dır (Anonim, 2016b).

Kahramanmaraş İlinde 2014 yllında 291.894 hektarlık alanda 263.199 ton dane mısır üretilmiş ve ortalama verim $902 \mathrm{da} / \mathrm{kg}$ olarak gerçekleşmiştir. Pazarcık ilçesinde ise aynı yıl 79.421 hektarlık alanda 76.111 ton dane misır üretimi gerçekleşmiş olup ortalama verim ise $958 \mathrm{da} / \mathrm{kg}^{\prime} \mathrm{d} ı r$. Bu veriler doğrultusunda dane mısır üretiminin yaklaşık \%28'lik kısmının Pazarcık ilçesinde yapıldığı görülmektedir.

Kahramanmaraş İlinde 2014 yılında 61.648 hektarlık alandan 300.294 ton silajlik misir üretimi elde edilmiştir. Ortalama verim ise $4.871 \mathrm{da} / \mathrm{kg}$ olarak gerçekleşmiştir. Pazarcık ilçesi için 2014 yılında 13.000 hektarlık alanda 84.500 ton silajlık misir üretimi gerçekleşmiş olup ortalama verim ise 6.500 da/kg'dır. Bu veriler doğrultusunda silajlık mısır üretiminin \%28'lik kısmının Pazarcık ilçesinde yapıldığı görülmektedir.

Son yıllarda Türkiye'de mısır üretimin ekonomik analizi ve maliyeti üzerine bazı çalışmalar yapılmıştır (Taşdan, 2005; Tuvaç ve ark., 2009; Alemdar ve ark., 2014, Çarkacı ve ark., 2016) Ancak, özellikle yerel düzeyde yapılacak çalışmalara ihtiyaç vardır.

$\mathrm{Bu}$ araştırmanın amacı, Kahramanmaraş ili Pazarcık ilçesinde mısır üretimi yapan çiftçilerin sosyodemografik özelliklerini belirlemek ve misır faaliyetinin ekonomik analizini ortaya koymaktır.

\section{MATERYAL VE METOT}

\section{Materyal}

$\mathrm{Bu}$ araştırmanın materyalini Kahramanmaraş ili Pazarcık ilçesinde, mısır üretim faaliyeti yapan 55 çiftçi ile Mayıs - Temmuz 2015 tarihleri arasında yüz yüze anket yolu ile elde edilen birincil veriler oluşturmaktadır.

Dane ve silajlık mısır üretiminin Kahramanmaraş Il genelinde yaklaşık \%30'unun Pazarcık İlçesinde yapıldığı için araştırma kapsamına Pazarcık ilçesi alınmıştır. Pazarcık İlçe Tarım Müdürlüğü kayıtlarından bu bölgedeki en çok mısır üretimi yapılan Narlı beldesindeki 7 köy gayeli olarak seçilmiştir.

\section{Metot}

\section{Araştırmanın evreni ve örneklemi}

Araştırmanın ana kitlesini Kahramanmaraş ili Pazarcık ilçesinde mısır üretim faaliyeti yapan işletmeler oluşturmaktadır. Örneklem büyüklüğü hesabı \%10 hata seviyesine göre yapılmıştır.

Tarım ekonomisi alanında yapılmakta olan bilimsel araştırmalarda örnekleme birimi olarak işletme arazisi yeterli görülmektedir. Yine bu araştırmada da 
dane ve silajlık mısır yetiştiren işletmeler esas alındığından dolayı, işletmelerin 2014 yılında dane ve silajlık mısır üretimine ayırdıkları arazi büyüklüğü kriteri esas alınarak araştırmanın popülâsyonu oluşturulmuştur. Örnek büyüklügünün hesaplanmasinda

$$
\mathrm{n}=\frac{\mathrm{N} \cdot \mathrm{z}^{2} \cdot \sigma^{2}}{\mathrm{~d} \cdot(\mathrm{N}-1)+\mathrm{z}^{2} \cdot \sigma^{2}}
$$

formülü kullanılmıştır. Bu formülde;

n: Örnek büyüklüğü

$\mathrm{N}$ : Anakitle büyüklüğü

$\sigma^{2}$ : Anakitle varyansı

d:Hata değeridir. Tahmin etmek istediğimiz gerçek aritmetik ortalamaya ne kadar yaklaşmak istediğimizi ifade eder. Bir başka ifadeyle, gerçek anakitle parametresi için hata değeridir.

z: Kabul edilen hata oranına göre standart normal dağılım tablosundaki z değeridir (Miran, 2002).

$n=\frac{275 \cdot(1,65)^{2} \cdot 37^{2}}{7,4 \cdot(275-1)+(1,65)^{2} \cdot 37^{2}}=54,72$

İşletme sayısı belirlenirken, anketlerin bir kısmının gerçekleri yansitmayacağ etmeyeceği düşünülerek \%10 (5 tane) yedek anket yapılmış, ancak değerlendirme 55 anket üzerinden yapılmıştır.

Buna göre 55 kişilik örneklem büyüklüğü araştırma evrenini temsil edebilecektir. Örneklem yöntemi olarak da basit tesadüfî örnekleme yöntemi kullanılmıştır. Bu örnekleme yönteminde, örnek içinde yer alan denekleri istatistiksel olarak tesadüfî yollarla belirlenmektedir.

\section{Verilerin Analizinde Uygulanan Yöntem}

Çalışmada kullanılan veriler 2014 üretim döneminin sonunu (Ekim-Aralık) temsil etmektedir. Araştırmada anketler yoluyla toplanan mali verilerden hareketle Kahramanmaraş ili Pazarcık ilçesinde üretilen dane ve silajlık mısırın birim ürün maliyeti hesaplanmıştır. $\mathrm{Bu}$ mali değerler araştırma bölgesi için işletmelerin tartılı ortalamasını ifade etmektedir. Üretim faaliyeti ile ilgili ortalama mali değerler, örnek işletmelerde, toplam dane ve silajlık misır ekim alanına bölünerek birim alana düşen masraflar saptanmıştır.

Gayrisafi üretim değeri (GSÜD) elde edilen ürün miktarı ile satış fiyatı ile çarpılarak, brüt kar gayrisafi üretim değerinden değişen masraflar toplamı çıkarılarak, net kar ise gayrisafi üretim değerinden üretim masrafları toplamı çıkarılarak hesaplanmıştır. Bütün hesaplamalar işletmeler ortalamasında birim alana göre (dekar) yapılmıştır.

\section{ARASTTIRMA BULGULARI}

\section{Çiftçilerin Sosyo-Demografik Özellikleri}

Araştırma kapsamında ele alınan işletmelerde çiftçilerin yaşları 27 ile 77 arasında değişmekle beraber çiftçilerin ortalama yaşı yaklaşık 55 yıldır. Çiftçilerin ortalama tarımsal faaliyet tecrübesi 32,8 yıl ve misır üretim deneyimi ise 11 yıldır. Iş̧letmelerde ortalama aile nüfusu 3,5 kişidir (Çizelge 1). İşletmelerdeki çiftçilerin \%7,3'ü lisans, 12,7'i ortaöğretim ve \%80,0'i ise ilköğretim mezunudur.

Çizelge 1. Çiftçilerin Sosyo-Demografik Özellikleri

\begin{tabular}{|c|c|c|c|}
\hline & Ortalama & Minimum & Maksimum \\
\hline $\begin{array}{l}\text { Tarımsal faaliyet } \\
\text { tecrübesi (yıl) }\end{array}$ & 32,8 & 5 & 60 \\
\hline Aile nüfusu (kişi) & 3,5 & 1 & 7 \\
\hline Yaş (yıl) & 54,9 & 22 & 77 \\
\hline $\begin{array}{l}\text { Misir üretim deneyimi } \\
\text { (yll) }\end{array}$ & 11,0 & 2 & 30 \\
\hline
\end{tabular}

\section{Çiftçilerin mısır üretimi yapma nedeni}

Bölgedeki çiftçilerin mısır üretimi yapma nedenleri arasında yarısından fazlasını $(\% 54,6)$ üretim kolaylığının olduğu tespit edilmiştir (Çizelge 2). Son 15 yılda mısır üretimi konusundaki devlet desteklerinin üreticinin mısır tarımını tercih etmesi konusunda büyük etkisi bulunmaktadır. Araştırma bölgesindeki coğrafi ve ekolojik koşullar, pazarlama imkanları, bölgedeki sulama kanallarının üretime etkisi, makineli tarım yapılabilme durumu, iş gücü ihtiyacının diğer tarım ürünlerine göre daha düşük olması gibi etkenler doğrultusunda çiftçilere üretim kolaylığı sağladığından mısır tarımına ilginin arttığı söylenebilir.

Çizelge 2. Misır üretimi yapma nedeni

\begin{tabular}{|l|r|r|}
\hline Mısır üretimi yapma nedeni & $\begin{array}{r}\text { Çiftçi } \\
\text { sayısı }\end{array}$ & $\%$ \\
\hline Arazi yapısı & 1 & 1,8 \\
\hline Satış garantisi & 12 & 21,8 \\
\hline Verim oranları & 10 & 18,2 \\
\hline Üretim kolaylığı & 30 & 54,6 \\
\hline $\begin{array}{l}\text { Bölgede mısır üretimine } \\
\text { duyulan ihtiyaç }\end{array}$ & 2 & 3,6 \\
\hline Toplam & 55 & 100,0 \\
\hline
\end{tabular}

\section{Çiftçilerin kooperatife üyelik durumu}

Tarımsal üretimin ekonomik, sosyal, teknik ve ekolojik bakımdan sürdürülebilir başarıya ulaşmasında en önemli faktörlerden birisi üreticilerin örgütlü olmasıdır. Üreticilerin örgütlenmesinde öne çıan yöntemlerden birisi kooperatifler şeklinde örgütlenmektir. Kooperatifler girdi tedariki, ürün pazarlama ve riski azaltma gibi alanlarda üreticilere avantajlar sağlamaktadır (Şahin ve ark., 2013). Araştırma bölgesinde işletmecilerin \%83,6'sı herhangi 
bir kooperatife üyeyken, \%16,4'ü herhangi bir kooperatife üye değildir. $\mathrm{Bu}$, bize bölgede kooperatifleşme bilincinin yüksek olduğunun göstermektedir. Kooperatifçilik, gelir dağılımından zarar görenlerin, bu zararları etkisiz hale getirmede denge oluşturduğundan üreticilerden tarafından tercih edildiği söylenebilir.

\section{Tarımsal alet ve makine sahip olma durumu}

Tarımsal mekanizasyonun amacı insan iş gücünün verimini arttırarak yapılan işin maliyetini düşürmektir. $\mathrm{Bu}$, direkt olarak birim iş için sarf edilen zamanın azaltılması veya endirekt olarak birim alandan elde edilen verimin arttırılması ile gerçekleşir. Makineli tarım sayesinde insan gücünden çok daha kuvvetli olan motor gücünden istifade edilir. Toprak işleme, ekim, dikim, hasat, harman, nakliye, işleme gibi işlemler makine ile daha iyi yapılır (Tezer ve Sabanc1, 2001).

Araştırma bölgesindeki işletmelerin \%81,8'i tarımsal alet ve makineye sahipken, $\% 18,2$ ' $\mathrm{i}$ ise alet ve makineye sahip olmadığı tespit edilmiştir. Bu duruma göre, tarımsal mekanizasyon araçları olarak da adlandırılan bu ürünler tarımsal üretimde işgücü verimliliğini artıran, maliyetleri düşüren, modern üretim teknolojilerinin kullanılmasını ve işlemlerin zamanında agroteknik ihtiyaçlara uygun şekilde yapılmasını sağlayarak ürün kalitesini ve verimini artıran önemli bir tarımsal üretim girdileri grubunu oluşturduğu söylenebilir. Araştırma bölgesindeki işletmelerin \%81,8'i tarımsal alet ve makineye sahip olması bölgedeki üreticilerin günümüz şartlarındaki teknolojiyi kullandıklarının bir göstergesidir.

\section{Çiftçilerin sosyal güvence durumu}

Araştırma bölgesindeki çiftçilerin \%92,7'sinin sosyal güvencesi varken, \%8,3’ünün sosyal güvencesinin olmadığ $\breve{g}_{1}$ belirlenmiştir. Bu durum bize, ilerleyen, gelişen ve bilinçlenen bir toplum olma yolunda ilerlediğimizi ve bir nevi çiftçiliğin daha ciddi bir meslek grubu olarak icra edildiğinin göstergesidir. Sosyal güvencesi olan çitçilerin ise büyük bir çoğunluğunun $(\% 66,6)$ tarım bağ-kur'lu olduğu tespit edilmiştir. Bu durum bize, yapmış oldukları tarımsal faaliyetlerden dolayı Ziraat odalarına kaydolan ya da ziraat odalarının bulunmadığı yerlerde tarım il/ilçe müdürlüklerine kaydolduğunu göstermektedir.

\section{Mısır tarımı dışında başka gelir kaynağı olma durumu}

Araştırma bölgesindeki çiftçilerin \%90,9'unu mısır tarımı dışında başka gelir kaynağına sahipken, \%9,1'inin mısır tarımı dışında başka gelir kaynağına sahip olmadığı tespit edilmiştir. Buda bize araştırma bölgesindeki çiftçilerin genellikle makineli tarım olarak yapılan mısır tarımının yanında, diğer bitkisel ürünlerin üretimi ile hayvancılık ve ticari faaliyetlerde bulunulduğunun bir göstergesidir. Bunun yanında makineli tarım yapılmasının, mısır üretiminin çiftçiler için ek gelir kaynağı olarak görülme olasılığını arttırdığı söylenebilir.

\section{Mısırda sulama ihtiyacının karşılanma durumu}

Çiftçilerin mısırda sulama ihtiyacının en çok sulama kanalından $(\% 76,4)$ karşılandığı tespit edilmiştir. Bu durum bize sulu tarım ürünü olan mısır ekimin bölgedeki sulama kanalının ve diğer sulu tarım arazilerinin etkisiyle misır tarımının kolay yapılabildiğinin göstergesidir.

\section{Çiftçilerin mısır satışından memnun olma durumu}

Araştırma bölgesinde işletmelerin mısır satışından $\% 83,6$ 'sının memnun olmadığ 1 ve \%16,4'ünün misır satışından memnun olduğu tespit edilmiştir. Bu durum bize, bölgede üretimi tercih edilen misır bitkisinin, dolaylı olarak büyük ölçüde üretim kolaylığından kaynaklandığını, mısır üretiminin masraf unsuruna bakıldığında devletin destekleme oranlarının düşük olduğunu, devletin belirlediği alım fiyatlarının aslında sadece ofislerde uygulandığını ve küçük işletmelerin ofislere ürün vermede pek imkanı bulunmadığı, tüccar alım fiyatlarını masraflarla orantılandığında kar oranlarının düşük düzeyde olduğunu söyleyebilir. $\mathrm{Bu}$ etkenler göz önüne alındığında çiftçilerinde bu durumdan memnun olmadıkları gözlemlenmiştir.

\section{Mısır üretiminin en büyük problemi}

Çiftçilerin mısır üretiminin en büyük probleminin $\% 43,6$ 'sını üretim masraflarının fazlalığından şikayetçi olduğu tespit edilmiştir. Üretim masraflarının fazlalığ sulama, gübre, makineli tarım ihtiyacı vb.) üretimdeki girdi maliyetlerinin yüksek fakat satış fiyatlarının istenilen oranda olmamasından üreticiye düşük kar payları bırakmaktadır. Bu durum üreticilerin mısır tarımındaki en önemli sorunu olduğu söylenebilir.

Çizelge 3. Mısır üretiminin en büyük problemi

\begin{tabular}{|l|r|c|}
\hline $\begin{array}{l}\text { Mısır üretiminin en büyük } \\
\text { problemi }\end{array}$ & $\begin{array}{r}\text { Çiftçi } \\
\text { sayısı }\end{array}$ & \multicolumn{1}{c|}{$\%$} \\
\hline Sulama & 6 & 10,9 \\
\hline Desteklerin yetersizliği & 13 & 23,6 \\
\hline Üretim masraflarının fazlalığı & 24 & 43,6 \\
\hline Diğer & 12 & 21,9 \\
\hline Toplam & 55 & 100,00 \\
\hline
\end{tabular}

Dane misırda gayri safi üretim değeri ve brüt kar

Araştırma kapsamında anket yapılan işletmelerde ortalama dane mısır ekim alanı 81,48 dekar, ortalama verim $1.080,43 \mathrm{~kg} / \mathrm{da}$ ve dane misır $\mathrm{kg}$ fiyatı ise 0,58 
TL'dir. Elde edilen bu verilerden GSÜD 626,65 TL/da olarak hesaplanarak, dane mısırın değişken masraflar toplamı 441,61 TL/da, çiftçinin eline geçen dekara brüt karı ise 185,04 TL/da olarak belirlenmiştir (Çizelge 4).

Çizelge 4. Dane mısır için dekara brüt kâr (TL/da)

\begin{tabular}{|c|c|c|}
\hline $\begin{array}{c}\text { Gayri Safi } \\
\text { Uretim Değeri } \\
\text { (GSÜD) (TL/da) }\end{array}$ & $\begin{array}{c}\text { Toplam } \\
\text { Değisken } \\
\text { Masraf (TL/da) }\end{array}$ & $\begin{array}{c}\text { Brüt Kâr } \\
\text { (TL/da) }\end{array}$ \\
\hline 626,65 & 441,61 & 185,04 \\
\hline
\end{tabular}

Silajlık mısırda gayri safi üretim değeri ve brüt kar

Araştırma kapsamında anket yapılan işletmelerde ortalama silajlı misır ekim alanı 70,89 dekar, ortalama verim $5.188,89 \mathrm{~kg} / \mathrm{da}$ ve silajllk misır $\mathrm{kg}$ fiyatı ise 0,12 TL'dir. Elde edilen bu verilerden GSÜD 622,67 TL/da olarak hesaplanarak, silajlık misırın değişken masraflar toplamı 476,35 TL/da, çiftçinin eline geçen dekara brüt karı ise 146,32 TL/da olarak belirlenmiştir (Çizelge 5).
Çizelge 5. Silajlık mısır için dekara brüt kâr (TL/da)

\begin{tabular}{|c|c|c|}
\hline $\begin{array}{c}\text { Gayri Safi } \\
\text { Uretim Değeri } \\
\text { (GSÜD) (TL/da) }\end{array}$ & $\begin{array}{c}\text { Toplam } \\
\text { Değişken } \\
\text { Masraf (TL/da) }\end{array}$ & $\begin{array}{c}\text { Brüt Kâr } \\
\text { (TL/da) }\end{array}$ \\
\hline 622,67 & 476,35 & 146,32 \\
\hline
\end{tabular}

İşletmeler Ortalamasında Dane Mısır Üretim Maliyet Hesabi

İşletmeler de dane mısır üretimi için; dekara toplam masraf içindeki değişken masrafların payı \%81,80, sabit masrafların payı ise $\% 18,20$ olarak hesaplanmıştır. Değişken masraflar içerisindeki en büyük pay ise gübreleme ve işçiliği \%24,08 olarak belirlenmiştir, bunu takip eden diğer değişken masraflar ise tohum, sulama ve iş̧̧iliği olduğu görülmüştür. Bölgede ortalama dane misır ana ürün verimi 1080,43 kg/da olarak bulunmuştur. Buna bağh olarak $1 \mathrm{~kg}$ dane mısır maliyeti 0,49 TL, satış fiyatı devlet desteği dahil 0,584 TL, net kar ise 0,094 TL olarak hesaplanmıştır.

Çizelge 6. İşletmeler Ortalamasında Dane Mısır Üretim Maliyeti

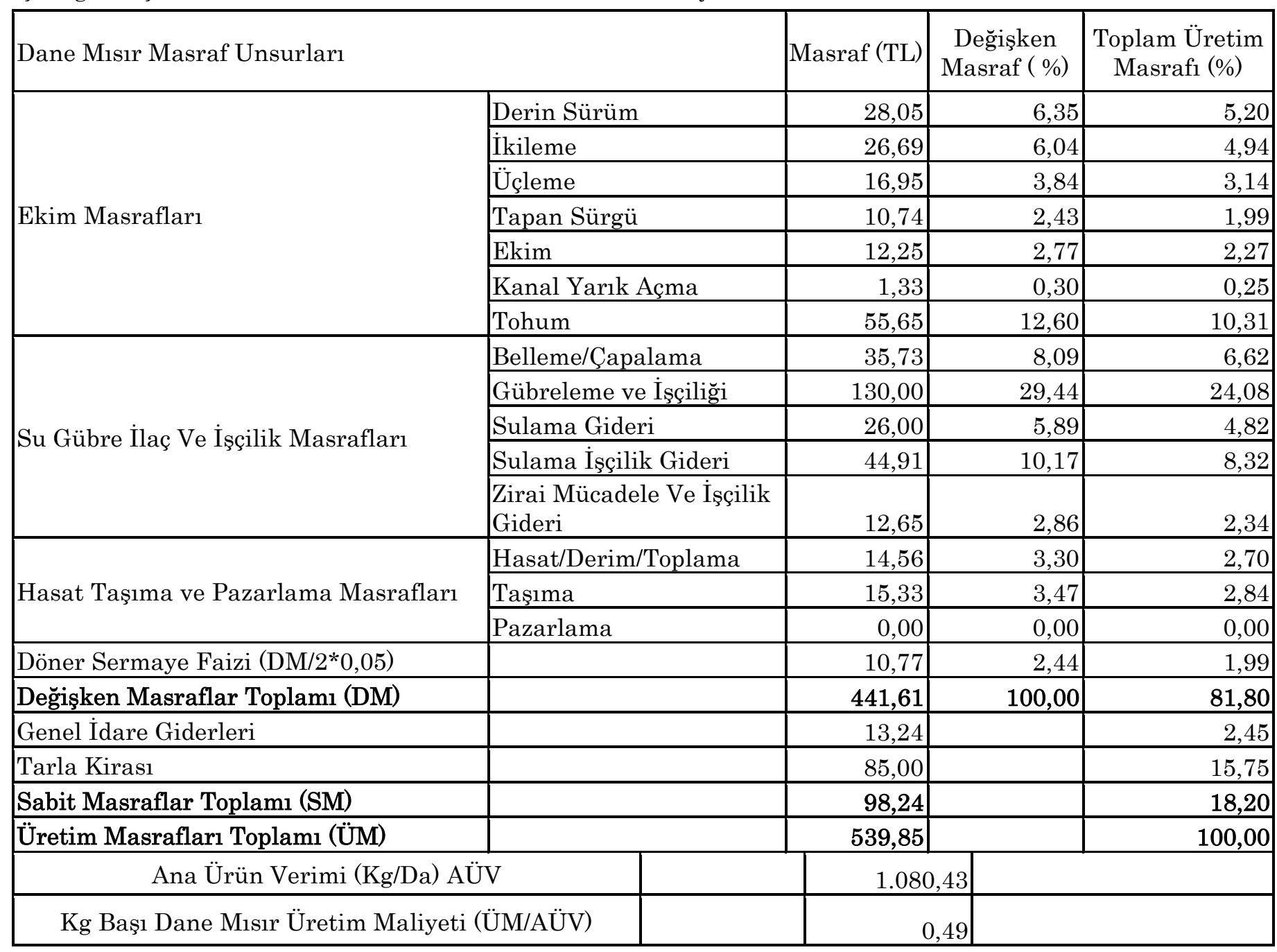


İşletmeler Ortalamasında Silajlık Mısır Üretim Maliyet Hesabı

İşletmeler de silajlık mısır üretimi için; dekara toplam masraf içindeki değişken masrafların payı \%83,44, sabit masrafların payı ise \%16,56 olarak hesaplanmıştır. Değişken masraflar içerisindeki en büyük payı ise $\% 22,25^{\prime}$ lik oranla gübreleme ve işçiliği masraflarının aldığı belirlenmiştir. Bunu diğer değişken masraflardan tohum, sulama ve iş̧̧liği ile silajlık mısır maliyetlerine önemli ölçüde etki eden taşıma masrafları takip etmektedir. Bölgede ortalama silajlık misır ana ürün verimi $5188,89 \mathrm{~kg} / \mathrm{da}$ olarak bulunmuştur. Buna bağlı olarak $1 \mathrm{~kg}$ silajlık mısır maliyeti 0,11 TL, satış fiyatı devlet desteği dahil 0,122 TL, net kar ise 0,012 TL olarak hesaplanmıştır.

Çizelge 7. İşletmeler Ortalamasında Silajlık Mısır Üretim Maliyeti

\begin{tabular}{|c|c|c|c|c|}
\hline \multicolumn{2}{|l|}{ Silajlık Mısır Masraf Unsurları } & $\begin{array}{c}\text { Masraf } \\
(\mathrm{TL})\end{array}$ & \begin{tabular}{c|} 
Değişken \\
Masraf (\%) \\
\end{tabular} & $\begin{array}{l}\text { Toplam Üretim } \\
\text { Masrafı }(\%) \\
\end{array}$ \\
\hline \multirow{7}{*}{ Ekim Masrafları } & Derin Sürüm & 24,85 & 5,22 & 4,35 \\
\hline & İkileme & 24,70 & 5,19 & 4,33 \\
\hline & Üçleme & 11,59 & 2,43 & 2,03 \\
\hline & Tapan Sürgü & 11,11 & 2,33 & 1,95 \\
\hline & Ekim & 12,00 & 2,52 & 2,10 \\
\hline & Kanal Yarık Açma & 0,00 & 0,00 & 0,00 \\
\hline & Tohum & 61,76 & 12,97 & 10,82 \\
\hline \multirow{5}{*}{ Su Gübre İlaç ve İş̧̧̧ilik Masrafları } & Belleme/Çapalama & 31,96 & 6,71 & 5,60 \\
\hline & Gübreleme ve İşçiliği & 127,00 & 26,66 & 22,25 \\
\hline & Sulama Gideri & 26,00 & 5,46 & 4,55 \\
\hline & Sulama İşçilik Gideri & 54,80 & 11,50 & 9,60 \\
\hline & $\begin{array}{l}\text { Zirai Mücadele ve İşçilik } \\
\text { Masrafı }\end{array}$ & 13,24 & 2,78 & 2,32 \\
\hline \multirow{3}{*}{$\begin{array}{l}\text { Hasat Taşıma ve Pazarlama } \\
\text { Masrafları }\end{array}$} & Hasat/Derim/Toplama & 15,00 & 3,15 & 2,63 \\
\hline & Taşıma & 50,73 & 10,65 & 8,89 \\
\hline & Pazarlama & 0,00 & 0,00 & 0,00 \\
\hline Döner Sermaye Faizi $\left(\mathrm{DM} / 2^{*} 0,05\right)$ & & 11,61 & 2,44 & 2,03 \\
\hline Değişken Masraflar Toplamı (DM) & & 476,35 & 100,00 & 83,44 \\
\hline Genel İdare Giderleri & & 14,29 & & 2,50 \\
\hline Tarla Kirası & & 80,25 & & 14,06 \\
\hline Sabit Masraflar Toplamı (SM) & & 94,54 & & 16,56 \\
\hline Üretim Masrafları Toplamı (ÜM) & & 570,89 & & 100,00 \\
\hline Ana Ürün Verimi (Kg/Da) AÜV & & \multicolumn{2}{|c|}{$5.188,89$} & \\
\hline $\begin{array}{l}\text { Kg Başı Silajlık Mısır Üretim Maliyeti } \\
\text { (ÜM/AÜV) }\end{array}$ & & \multicolumn{2}{|c|}{0,11} & \\
\hline
\end{tabular}

\section{SONUÇ ve ÖNERILER}

Kahramanmaraş ili Pazarcık ilçesinde mısır üretimi yapan işletmelerin en büyük probleminin üretim masraflarının fazlalığı olduğu belirlenmiştir. Bunun yanında bölgede mısır üretiminde girdi maliyetlerinin diğer tarım ürünlerine kıyaslandığında hemen hemen aynı olduğu saptanmıştır. Ancak mısır tarımı devlet desteği ve mısır üretimindeki makineli tarımdan kaynaklı üretim kolaylığı nedeniyle çiftçiler tarafindan tercih edilmektedir.

Bölgedeki çiftçilere yapılan anket çalışması neticesinde misır yetiştiriciliği ile ilgili teknik bilgilerinin ve pazarlama becerilerinin yetersiz olduğu tespit edilmiştir. Bu kapsamda, çiftçilerin yapmış oldukları tarımsal faaliyetlere yönelik bilgi ve tecrübelerini artıracak yayım çalışmalarının (tarla günleri, köy toplantıları, çiftçi kursları vb) yapılması gerekmektedir.

$\mathrm{Bu}$ ve benzeri araştırma bulguları, tarımsal üretim faaliyetinde bulunan tarım işletmeleri için son derece önemli ve yol göstericidir. Çünkü tarım işletmesi yöneticilerinin hangi üretim dalına ne kadar masraf yapacağını ve bu masraf karşılığında ne kadar gelir elde edeceğini bilmesi, işletmenin karını yükseltmesi açısından önemlidir. Bölgedeki tarım işletmelerinin kayıt tutmamaları ve üretim dalları arasında karşılaştırma yapmak için gerekli maliyet analizleri yapmamaları nedeniyle, bu çalışmanın bölgedeki işletme yöneticilerine faydalı olacağ düşünülmektedir. 


\section{TEŞEKKÜR}

$\mathrm{Bu}$ çalışma, Nuran ORTASÖZ'ün yüksek lisans tezinden türetilmiştir.

\section{KAYNAKLAR}

Alemdar T, Seçe, A, Demirdöğen A, Öztornacı B, Aykanat S 2014. Çukurova Bölgesinde Başlıca Tarla Ürünlerinin Üretim Maliyetleri ve Pazarlama Yapıları. Tepge Yayın No: 230, Ankara.

Anonim 2016a. https://arastirma.tarimorman.gov.tr /ktae/Belgeler/brosurler/M\%C4\%B1s\%C4\%B1r\%20 Tar\%C4\%B1m\%C4\%B1.pdf

Anonim 2016b. Türkiye İstatistik Kurumu, Bitkisel Üretim İstatistikleri. http://www.tuik.gov.tr (Erişim Tarihi: 21/12/2016)

Çarkacı DA Yokuş S, Ölmez O, Çelik Y, Karadavut U 2016. Konya Yöresinde Yetiştirilen Mısır Bitkisinin Üretim Girdi ve Maliyetlerinin Belirlenmesi. XII.

Ulusal Tarım Ekonomisi Kongresi, 25-27 Mayıs 2016, Isparta. Bildiriler Kitabı:1763-1768.

Miran B 2002. Temel İstatistik. Ege Üniversitesi Basımevi, İzmir.

Şahin A, Cankurt M, Günden C, Miran B, Meral Y 2013. Türkiye'de Tarımsal Kalkınma Kooperatiflerinde Ortak -Kooperatif İlişkileri. KSÜ Doğa Bil. Derg., 16(2):21-33.

Taşdan K 2005. Türkiye Mısır Piyasası. Çukurova Üniversitesi Fen Bilimleri Enstitüsü Tarım Ekonomisi Anabilim Dalı, Doktora Tezi. 213 s.

Tezer E, Sabancı A 2001. Tarımsal Mekanizasyon I. Ç.Ü. Zir. Fak. Yay. No:44, Adana.

Tuvanç İA, Dağdemir V 2009. Erzurum İli Pasinler İlçesinde Silajlık Mısır Üretim Maliyetinin Tespiti Üzerine Bir Araştırma. Atatürk Üniversitesi, Ziraat Fakültesi Dergisi 40 (1):61-69. 